\title{
Aristida tuitensis (Poaceae: Aristideae), a New Species from El Tuito, Jalisco, Mexico
}

\author{
Jorge G. Sánchez-Ken and Patricia Dávila A. \\ Instituto de Biología, U.N.A.M., Depto. de Botánica, Herbario Nacional, Apartado Postal 70- \\ 233, 04510 México, D.F., Mexico
}

AbSTRACT. A new species, Aristida tuitensis from El Tuito, Jalisco, Mexico, is described and illustrated, and its distribution and ecology are discussed. It belongs to Aristida sect. Streptachne and is distinguished from A. schiedeana by its spreading inflorescence, shorter spikelets, and the lack of dentate glumes, and from $A$. hintonii by its inflorescence shape, the internode, and sheath length. A table summarizing the differences and similarities among the three species is presented.

As part of research to revise the genus Aristida L. section Streptachne (R. Brown) Domin, some unusual specimens of Aristida were collected in the area of El Tuito, Jalisco, Mexico, in early 1993. The material was initially identified as $A$. schie. deana, a common grass in the area. However, with additional studies of these specimens, as well as other collections from IBUG and COCA, it was realized that these specimens represent a new species.

Aristida tuitensis Sánchez-Ken \& P. Dávila, sp. nov. TYPE: Mexico. Jalisco: Municipio El Tuito, El Tuito, 9 a $10 \mathrm{~km}$ sobre la brecha a las Minas del Cuale (E de El Tuito), elev. 1900 m, 13 ene. 1991, J. Sánchez-Ken, M. May. field \& B. Westlund 500 (holotype, MEXU; isotypes, ENCB, IBUG, MICH, MO). Figure 1.

Gramen perenne caespitosum; internodia ramosa, 915 infra inflorescentiam; vaginae coriaceae internodiis longiores; ligulae externae presentes; spiculae effusae binatae; glumae infernae glumis supernis longiores; glumae infernae no dentatae, 3-nervatae, nervis centrales conspicui, nervi laterales inconspicui; calli $0.7-1.0 \mathrm{~mm}$ longi; lemmata glumis breviores vel eas aequantes raro; columnae lemmatum 6-10 mm longae; aristae laterales absentes; antherae 3-4 $\mathrm{mm}$ longae.

Perennial tufted grass, erect; pseudorhizome present, 80-120 $\mathrm{cm}$ long. Internodes 2.09.0(-12.0) $\mathrm{cm}$ long, 1-2 $\mathrm{mm}$ diam., glabrous, straight, terete, bamboo-like, branched, with 9-15 internodes below the inflorescence; nodes glabrous, inconspicuous. Leaf sheaths $3-9 \mathrm{~cm}$ long, 4-6 mm wide, longer than the internodes, strongly overlapping, glabrous, not striate, strongly coriaceous, in- cluding the margins; inner ligule ciliate, $0.2-0.3$ mm long; auricles lacking, sometimes a tuft of lateral hairs $2 \mathrm{~mm}$ long instead of the auricles in juvenile stages; outer ligule or contra ligule present; blade $10-50 \mathrm{~cm}$ long, 2-4 $\mathrm{mm}$ wide, linear, flat, straight to slightly flexuous when dry, adaxially scaberulous with scattered hairs toward the base, abaxially smooth or rarely scaberulous, with 7 main conspicuous nerves, but with 21,23 , or 25 nerves in total. Inflorescence an open panicle, 14-35 cm long, 12$20 \mathrm{~cm}$ wide; basal internode $18-70 \mathrm{~cm}$ long; peduncule 11-30 cm long, glabrous or scaberulous; branches 9-13(-15) cm long, branching until 5th order, ascendant, strongly spreading, with the spikelets located at the apex; pulvinus present in the axils of all branches and pedicels, glabrous; pedicels 5$18 \mathrm{~mm}$ long. Spikelets usually paired, $20-28 \mathrm{~mm}$ long from the base of glumes to the tip of the awn, spreading; glumes varying in size, usually the first larger than the second one, sometimes the second glume larger, persistent; first glume 4-8 mm long, to $1 \mathrm{~mm}$ wide, 3 -nerved, the two lateral nerves inconspicuous, glabrous, keeled and scabrous in the keel, apically acute and awned, not dentate, awn 0.5-2.0 mm long; second glume $6.0-7.5 \mathrm{~mm}$ long, to $1.0 \mathrm{~mm}$ wide, 1 -nerved, keeled and glabrous in the keel, apically obtuse and awned, not dentate, the awn 0.5-1.0 mm long; calluses $0.7-1.0 \mathrm{~mm}$ long; lemma shorter than or sometimes as long as the glumes, 4.5-6.0 mm long without the column, 1.0-1.3 mm wide, convolute, 3 -nerved, terete, scaberulous in the upper third, not articulate with the column, not articulated; column 6-10 mm long, twisted, abaxially scaberulous, adaxially muricate, basally geniculate; awn 1, 8-10 mm long, straight, basally geniculate, thin; lateral awns lacking; palea 0.5-0.7 mm long, not keeled, smooth; lodicules 2, 1.0-1.2 mm long, hyaline; stamens 3 ; anthers $3-$ $4 \mathrm{~mm}$ long; stigma 1-2 mm long. Caryopsis not seen.

Distribution. Aristida tuitensis is endemic to the area of El Tuito in the state of Jalisco, northeast of Chamela. It occurs in a pine and oak forest that also contains some elements that are characteristic 
A
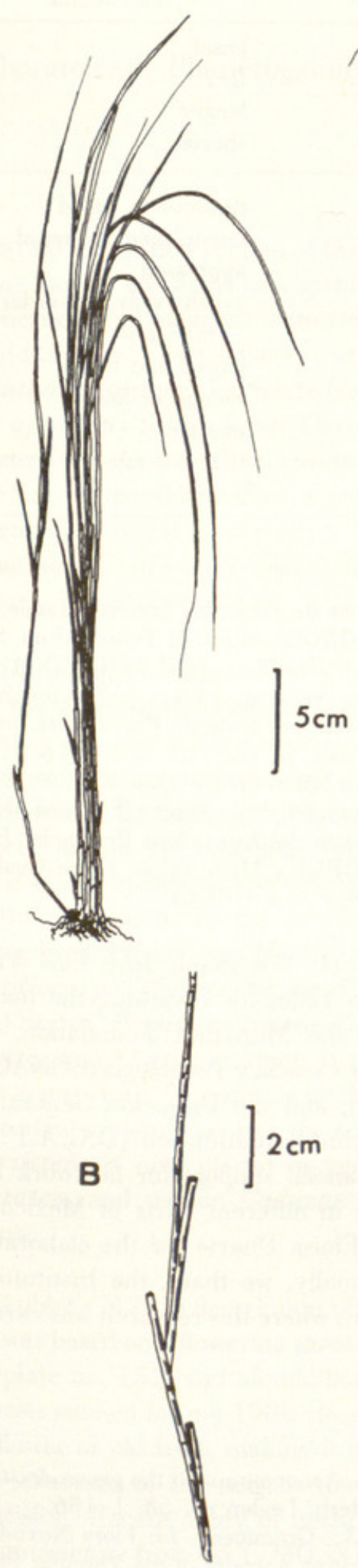

C

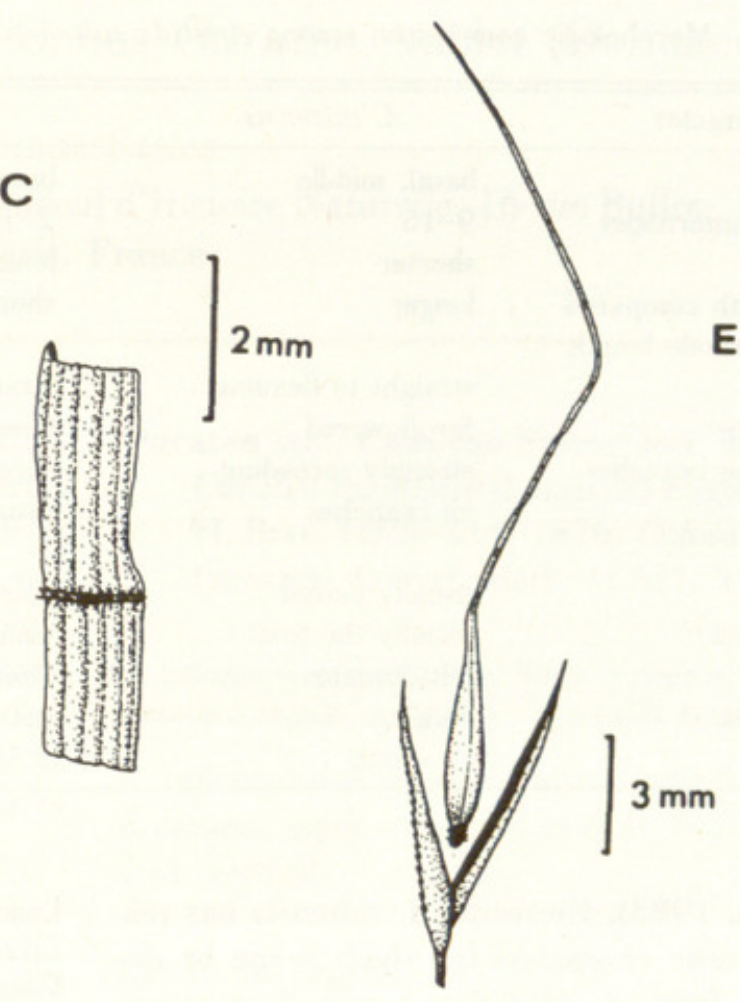

E

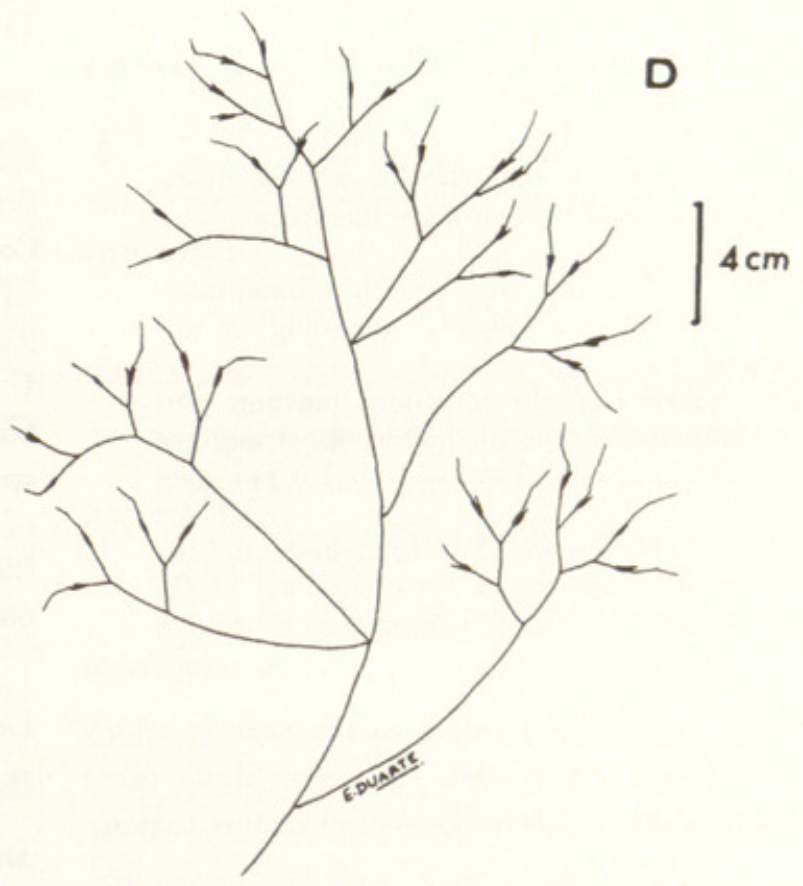

Figure 1. Aristida tuitensis Sánchez-Ken \& P. Dávila. - A. Habit. - B. Stem. - C. Adaxial and abaxial view of the leaf sheath. - D. Inflorescence. - E. Spikelet (all from Sánchez-Ken et al. 500).

of a tropical rainforest. Altitudinally, it ranges from 1300 to $1900 \mathrm{~m}$. The soils are reddish and usually sandy to clayish. Flowering occurs between September and January.
According to Henrard's (1929) criteria, this species belongs to Aristida sect. Streptachne. As shown by the herbarium annotations, this species was confused with A. schiedeana in Flora Novo-Galiciana 
Table 1. Morphologic comparison among Aristida tuitensis, A. hintonii, and A. schiedeana.

\begin{tabular}{llll}
\hline \hline \multicolumn{1}{c}{ Character } & \multicolumn{1}{c}{ A. tuitensis } & \multicolumn{1}{c}{ A. hintonii } & \multicolumn{1}{c}{ A. schiedeana } \\
\hline $\begin{array}{l}\text { Branching } \\
\text { Number of internodes }\end{array}$ & basal, middle & basal & basal \\
Stem & shorter & $2-10$ & $2-7$ \\
Sheath length compared & longer & longer & longer \\
with internode length & & shorter & shorter \\
Leaf shape & straight to flexuous & straight to flexuous & flexuous to coiled \\
Inflorescence & few-flowered & flowered & few-to many-flowered \\
Inflorescence branches & strongly spreading & spreading & appressed \\
Pulvinus & all branches & usually all branches & usually only first-order \\
& & & branches \\
Spikelet & usually paired & paired and triads & paired and triads \\
Larger glume & usually the first & usually the second & second or first \\
Glumes & not dentate & dentate & dentate \\
Lateral awns & lacking & $0.1-1.0 \mathrm{~mm}$ & $0.1-2.0$ mm \\
Anthers & $3-4$ mm & $1.5-2.0 \mathrm{~mm}$ & $1.5-2.0 \mathrm{~mm}$ \\
\hline
\end{tabular}

(McVaugh, 1983). However, A. tuitensis has reliable diagnostic characters by which it can be distinguished from A. schiedeana and A. hintonii, probably the two most closely related species (Table 1). A notable character of $A$. tuitensis is the relatively long anthers compared to the lemma body. To our knowledge, such long anthers have not been reported in any other species of the genus.

\section{Artificial Key to Three Related Species of ARISTIDA SECT. STREPTACHNE}

la. Anthers 3-4 mm long; sheaths not striate; inflorescence branches strongly spreading .....

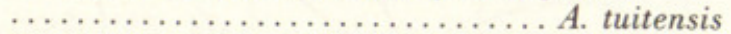

lb. Anthers 1.5-2 mm long; sheaths striate; inflorescence branches slightly spreading or appressed.

2a. Spikelets usually spreading; pulvinus usually in all branches; leaf blades straight to flexuous; lateral awns up to $1.0 \mathrm{~mm}$ long ....................... hintonii

2b. Spikelet appressed to branches; pulvinus in the branches of lst order; leaf blades flexuous to coiled; lateral awns up to 2.0 $\mathrm{mm}$ long $\ldots \ldots \ldots \ldots \ldots \ldots$ A. schiedecana

The specific epithet refers to the area in which the species was discovered, El Tuito. Many other taxa have recently been discovered in this region.

Paratypes. MEXICO. Jalisco: Mpio. Cuautitlán, Cerca de $10 \mathrm{~km}$ al sur-suroeste de las Joyas, Sierra de Manantlán, R. Guzmán 6120 (COCA); Mpio. El Cuale,
Lado este de las Minas de Zimapán, brecha a Cuale, $R$. Guzmán M. 6101a (IBUG); Mpio. El Tuito, $30 \mathrm{mi}$. S of Puerto Vallarta, A. A. Beetle et al. M-3610 (COCA); Al sur-sureste de Puerto Vallarta, $14 \mathrm{~km}$ por la brecha a Minas de Zimapán, $1 \mathrm{~km}$ al oeste de Providencia por la brecha El Tuito-El Cuale, R. Guzmán M. 6094 (COCA); Km 2 por la brecha a Minas de Zimapán, F. J. Santana M. 1196 (IBUG); Km 14 de la brecha El Tuito-Minas Zimapán, $1 \mathrm{~km}$ al oeste del Aserradero Provincia, F. J. Santana M. 1204 (IBUG); Mpio Talpa, Entre Cuale y Talpa, J. de la Torre V. s.n. (IBUG).

Acknowledgments. We thank José Luis Villaseñor and Oswaldo Téllez for reviewing the manuscript. We thank the McArthur Foundation, the Consejo Nacional de Ciencia y Tecnología (CONACyT CPECBN-021759), and the Dirección General de Asuntos del Personal Académico (D.G.A.P.A.U.N.A.M.) for financial support for fieldwork and botanical research in different parts of Mexico. A special thanks to Eloisa Duarte for the elaboration of the drawing. Finally, we thank the Instituto de Biología, U.N.A.M., where this research was carried out.

\section{Literature Cited}

Henrard, T. 1929. A monograph of the genus Aristida. Meded. Rijks-Herb. Leiden no. 58: 1-156.

McVaugh, R. 1983. Gramineae. In: Flora Novo-Galiciana: A Descriptive Account of the Vascular Plants of Western Mexico. Vol. 14. The Univ. Michigan Press, Ann Arbor. 


\section{$2 \mathrm{BHL}$ Biodiversity Heritage Library}

Dávila-Aranda, Patricia D. and Sanchez-Ken, Jorge. 1995. "Aristida tuitensis (Poaceae: Aristideae), a new species from El Tuito, Jalisco, Mexico." Novon a journal of botanical nomenclature from the Missouri Botanical Garden 5, 190-192.

View This Item Online: https://www.biodiversitylibrary.org/item/14665

Permalink: $\underline{\text { https://www.biodiversitylibrary.org/partpdf/16556 }}$

\section{Holding Institution}

Missouri Botanical Garden, Peter H. Raven Library

\section{Sponsored by}

Missouri Botanical Garden

\section{Copyright \& Reuse}

Copyright Status: In copyright. Digitized with the permission of the rights holder.

License: http://creativecommons.org/licenses/by-nc-sa/3.0/

Rights: https://biodiversitylibrary.org/permissions

This document was created from content at the Biodiversity Heritage Library, the world's largest open access digital library for biodiversity literature and archives. Visit BHL at https://www.biodiversitylibrary.org. 